Original Article

\title{
A STUDY TO ASSESS THE FACTORS INFLUENCING UNMET NEED OF FAMILY PLANNING AMONG MARRIED WOMEN IN SELECTED VILAGES OF UDUPI DISTRICT, KARNATAKA
}

\author{
Lekshmi A.R. ${ }^{1}$, Ansuya ${ }^{2} \&$ Manjula ${ }^{3}$ \\ ${ }^{1}$ Student M. Sc. (N), ${ }^{2,3}$ Assistant Professors \\ Department of Community Health Nursing \\ M anipal College of Nursing, Manipal University, M anipal, Karnataka, INDIA \\ Correspondence: \\ Ansuya \\ Assistant Professor, Department of Community Health Nursing, M anipal College Of Nursing Manipal \\ Manipal University, Manipal, Karnataka, India \\ Mobile : +91 95358 94558, Fax: 08202922572 E-mail : ansuya.bengre@manipal.edu
}

\begin{abstract}
:
Background: M illions of women worldwide who are sexually active, who would prefer to avoid becoming pregnant, but are not using any contraception, these women are considered to have an "unmet need" for Family Planning. The concept of "unmet need" points to the gap between some women's reproductive intensions and their contraceptive behaviour'. Bridging the gap can lead to a great success in the family planning programme and realization of the dream of stable population.
\end{abstract}

Objectives: To assess the unmet need of family planning and the factors influencing the unmet need among married women.

Materials and Methods: A descriptive survey was under taken among 280 married women selected using purposive sampling. Data were collected using structured questionnaire.

Results: About $41.1 \%$ of the total subjects had the unmet need for family planning in that $32.2 \%$ were having unmet need for spacing and $67.8 \%$ for limiting. M ajority (55.7\%) were not using family planning because of fertility related reasons. The study revealed that there was a significant association between unmet need and variables like age and number of living children. There was a significant association between unmet need and fertility related reasons.

Conclusion: Since the unmet need of family planning is existing, awareness of the public in relation to family planning should be ongoing especially to the general public with lower level of education.

Keywords: Family planning, factors influencing unmet need

\section{Introduction:}

India is the second populous country in the world. The current population of India is about 1.22 billion. Karnataka is the eight largest states in India in terms of Population. According to Population census of 2011, the Population of Karnataka is 6.11 corers. The Population of Karnataka has increased $17.20 \%$ as compared to last census of India in

\begin{tabular}{|c|}
\hline Access this article online \\
\hline Quick Response Code \\
\hline
\end{tabular}
1991. The main solution of the growing population is to implement the family planning programmes in India. Importance of the family planning programme as a device in controlling population explosion is universally recognized. The objective of family planning welfare programme in India is that people should adopt the small family norm to stabilize country's population. Since the launch of nationwide family planning programme in 1951 attempts have been made from time to time to encourage the women to accept and adopt contraception. In spite of efforts of the programmers there are women who have never used a method of family planning throughout their reproductive life.

A large number of women who are sexually active and would prefer to avoid or delay child bearing but are not using any contraception, are said to have an unmet need for family planning. ${ }^{1}$ This concept clearly indicates a gap between a woman's reproductive intention and 
contraceptive behaviour. There are over 35 million such women in India. Important reasons for unmet need include fertility related reasons, health concerns, fear of side effects, etc. The present study was conducted to find out the prevalence of unmet need and factors influencing it, which will be helpful in planning need based awareness programmes that in turn prevents unwanted pregnancies.

\section{Objectives of the study:}

To asses the unmet need of family planning and the factors influencing the unmet need among married women.

To find out association between unmet need of family planning and factors influencing unmet need.

\section{Materialsand M ethods:}

A descriptive survey was conducted among 280 married women between the age group of $18-45$ years residing in Athrady and Hirebettu villages of udupi district. Samples were selected by using non probability purposive sampling technique. Self-administered structured questionnaire was used to collect data. The background information of the sample were collected by using demographic proforma and factors influencing unmet need assessed by using structured questionnaire

\section{Results:}

Table 1: Distribution of sam ple characteristics :

Most (29.3\%) of the samples were in the age group of 31-35 years; educated up to secondary education (37.9\%). Majority (61.1\%) of the sample were housewives; (87.9\%) were Hindus; (56.7\%) were having two children and $52.1 \%$ had monthly income between Rs 3001-6000. Majority $(60 \%)$ of the samples had heard about family planning from health workers.

\section{Fig 1 : Description of unmet need of family planning:}

Among 280 samples about 165(59.\%) were using different family planning methods and $115(41 \%)$ were having the unmet need.

Table 2: Distribution of type of unmet need of family planning.

Data represented in table show that among 115 women with unmet need, $67.8 \%$ do not want any more children but they are not using family planning measures so they are having unmet need for limiting. About 32.2\% wanted children but like to postpone it and are not using family planning measures, so they are having unmet need for spacing. From this it is inferred that unmet need for limiting is more among women than spacing.

\section{Fig2: Description of factors influencingunmet need.}

Among 115 samples, majority $55.7 \%$ were not using family planning because of fertility related reasons, $53 \%$ are due to health concerns, fear of side effects 43.5 , objection to family planning $40.9 \%$, difficulty with use $36.5 \%$, husband's disapproval and religious restrictions $31.3 \%$, nonavailability and unsatisfactory services $24.3 \%$ and $21.7 \%$ due to lack of knowledge.

Table 3 : Association between unmet need and factors influencing unmet need of family planning.

The study revealed that there was a significant association between unmet need and fertility related reasons $\left(x^{2}=4.723, p=0.03\right)$. There is no significant association between unmet need and other variables factors. Hence it is inferred that unmet need is dependent on fertility related reasons and independent on other factors.

Table : 1 Frequency and percentage distribution of sample characteristics. $n=280$

\begin{tabular}{|l|r|r|}
\hline Sample characteristics & $\mathbf{f}$ & $\%$ \\
\hline Age in yrs & & \\
\hline$<20$ & 5 & 1.8 \\
\hline $21-25$ & 34 & 12.1 \\
\hline $26-30$ & 70 & 25 \\
\hline $31-35$ & 82 & 29.3 \\
\hline $36-40$ & 51 & 18.2 \\
\hline $41-45$ & 38 & 13 \\
\hline Educational status & & \\
\hline Illiterate & 14 & 5 \\
\hline Primary school & 95 & 33.9 \\
\hline Secondary school & 106 & 37.9 \\
\hline PUC & 27 & 9.6 \\
\hline Graduate & 30 & 10.7 \\
\hline Post graduate & 8 & 2.9 \\
\hline Religion & & \\
\hline Christian & 8 & 2.9 \\
\hline Hindu & 246 & 87.9 \\
\hline Muslim & 26 & 9.3 \\
\hline
\end{tabular}




\begin{tabular}{|l|r|r|}
\hline Sample characteristics & f & $\%$ \\
\hline Type of family & & \\
\hline Joint & 123 & 43.9 \\
\hline Nuclear & 157 & 56.1 \\
\hline Monthly income(Rs) & & \\
\hline$<3000$ & 26 & 9.3 \\
\hline $3001-6000$ & 146 & 52.1 \\
\hline $6001-9000$ & 95 & 33.9 \\
\hline$>9000$ & 13 & 4.6 \\
\hline Occupation & & \\
\hline Coolie & 61 & 21.8 \\
\hline House wife & 171 & 61.1 \\
\hline Private employee & 36 & 12.9 \\
\hline Govt employee & 12 & 4.3 \\
\hline No. of living children & & \\
\hline 1 & 82 & 29.3 \\
\hline 2 & 159 & 56.8 \\
\hline 3 & 30 & 10.7 \\
\hline$>3$ & 82 & 29.3 \\
\hline Source of information & & \\
\hline Health workers & 168 & 60 \\
\hline Family members & 15 & 5.4 \\
\hline Friends & 12 & 4.3 \\
\hline Mass media & 83 & 29.4 \\
\hline Others & 2 & 0.7 \\
\hline
\end{tabular}

Table 2 : Distribution of type of unmet need of family planning amongstudy population

$\mathrm{n}=115$

\begin{tabular}{|l|c|c|}
\hline Type of unmet need & $f$ & $\%$ \\
\hline Spacing & 37 & 32.2 \\
\hline Limiting & 78 & 67.8 \\
\hline
\end{tabular}

Fig 1 : Description of unmet need of family planning:

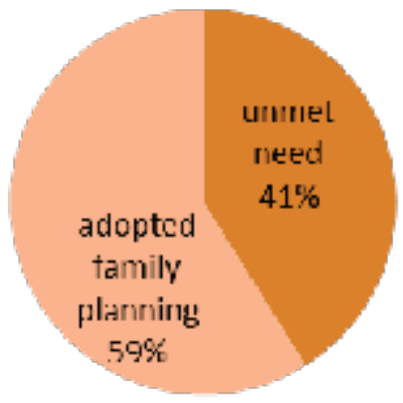

Table 3: Association between unmet need and factors influencing unmet need of family planning.

$n=115$

\begin{tabular}{|c|c|c|c|c|c|}
\hline Factors influencing & Unmet & $x^{2}$ value & $\mathrm{df}$ & P value & \\
\hline & need & & & & \\
\hline & Spacing & Limiting & & & \\
\hline Lack of knowledge & & & 0.214 & 1 & 0.643 \\
\hline Yes & 9 & 16 & & & \\
\hline No & 28 & 62 & & & \\
\hline Religious restriction & & & & & \\
\hline Yes & 14 & 22 & 1.083 & 1 & 0.298 \\
\hline No & 23 & 56 & & & \\
\hline Husband's disapproval & & & & & \\
\hline Yes & 12 & 24 & 0.032 & 1 & 0.857 \\
\hline No & 25 & 54 & & & \\
\hline Non availability & & & & & \\
\hline Yes & 12 & 16 & 1.936 & 1 & 0.164 \\
\hline No & 25 & 62 & & & \\
\hline Objection to family planr & ning & & & & \\
\hline Yes & 15 & 32 & 0.002 & 1 & 0.961 \\
\hline No & 22 & 46 & & & \\
\hline Health concerns & & & & & \\
\hline Yes & 21 & 40 & 0.302 & 1 & 0.583 \\
\hline No & 16 & 38 & & & \\
\hline Fear of side effects & & & & & \\
\hline Yes & 14 & 36 & 0.706 & 1 & 0.041 \\
\hline No & 23 & 42 & & & \\
\hline Difficulty with use & & & & & \\
\hline Yes & 11 & 31 & 1.085 & 1 & 0.291 \\
\hline No & 26 & 47 & & & \\
\hline Unsatisfactory services & & & & & \\
\hline Yes & 7 & 21 & 0.873 & 1 & 0.350 \\
\hline No & 30 & 57 & & & \\
\hline Fertility related reasons & & & & & \\
\hline Yes & 26 & 38 & 4.723 & 1 & $0.03^{*}$ \\
\hline No & 11 & 40 & & & \\
\hline
\end{tabular}

*significant at $\varangle 0.05$ level of significance

Fig 2 : Factors influencing unmet need :

$\mathrm{n}=115$

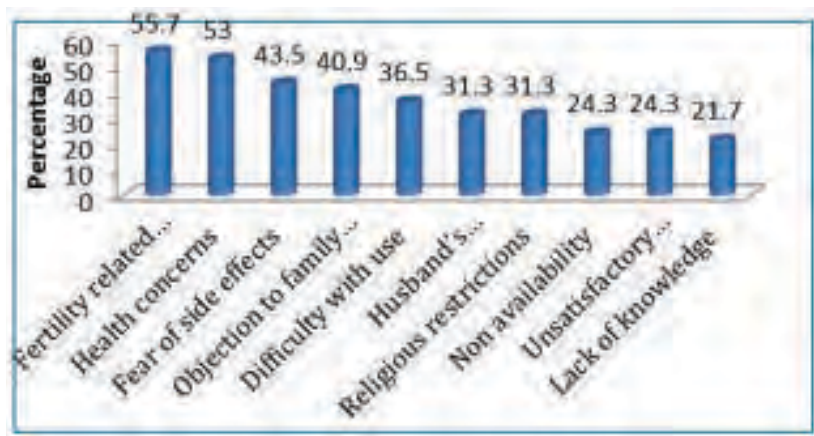




\section{Discussion :}

The present study shows that $41.1 \%$ of the samples were having unmet need, in this $67.8 \%$ have unmet need for limiting and $32.2 \%$ have unmet need for spacing. This was supported by a study conducted by Puri A, Garg S to find the unmet need for contraception in Delhi. The study reveals that $49.8 \%$ women had unmet need and in that $22.6 \%$ had unmet need for spacing and $27.2 \%$ had unmet need for limiting. Another study conducted by Cali S, Kalaca S, Sariyaka 0 reveals that about $43 \%$ of the samples were having unmet need in that $62 \%$ were having unmet need for limiting and $27.3 \%$ for spacing which is in agreement with the present study findings. ${ }^{3}$

The present study reveals that majority (55.7\%) were not using family planning because of fertility related reasons , $43.5 \%$ due to fear of side effects and $24.3 \%$ due to unsatisfactory services. This was supported by a study conducted by Govindaswamy P and Boadi $E$ to find the unmet need in Ghana.The study shows that most (34.6\%) of samples were not using contraception due to fertility related reasons. ${ }^{4}$ Another study conducted by Rama $\mathrm{R}$, Ghosh M , Battacharya S, Halder A, Chatterjee C, Naskar N with an aim to identify the factors influencing unmet need

\section{Reference:}

1. Saini NK, Bhasin SK, Sharma R, Yadav G. Study of unmet need for family planning in a resettlement colony of east delhi. Health and population - perspectives and issues. 2007;30(2):124-133.

2. Cali S, Kalaca S, Sariyaka O . Minimising missed oppurtunities: an approach to decrease the unmet need for family planning. European journal of contraception and reproductive health care.2004;9(4):285289.

3. Puri A, Garg S, M ehra M . Assesment of unmet need for contraception in an urban slum of Delhi. Indian journal of community medicine. 2004; 29(3):139-140.

4. Govindaswamy P,Boadi E. A decade of unmet need for contraception in Ghana : Programmatic and policy implications [internet] 2000 August. Availablefrom http://pdf.usaid.gov/pdf_docs/PNACK667.pdf

5. Ram R, Ghosh M N, Bhattacharya S, Halder A, Chatterjee C, Naskar N. Study of Unmet need for family planning among married women of reproductive age attending immunization clinic of Calcutta. Indian journal of community medicine. 2000;25(1):22-25.

6. Umbeli T, M ukhtar A, Abusalab MA. Study of unmet need for family planning in Dar Assalaam, Sudan. Eastern Mediterranean health journal.2005; 11(4): 594-600.

7. Thang MN, Anh DN. Accessibility and use of contraceptive in Vietnam. Indian Family planning perspectives.2002;28(4):214-219. for family planning in calcutta. The study shows that $25.5 \%$ of samples reason for not using contraceptive is fear of side effects and $27.5 \%$ unsatisfactory services. ${ }^{5}$

The present study shows a significant association between unmet need and fertility related factors $\left(x^{2}=4.723\right.$, $p=0.03$ ) and no association was found between unmet need and lack of knowledge, religious restriction, availability, husband's disapproval, health concerns. Thang MN, Anh DN conducted a study to assess the accessibility and use of contraceptive among 5,310 married women of reproductive age in Vietnam. The study revealed that unmet need for family planning was $78.9 \%$ and there was a significant association between availability and contraceptive use ( $95 \% \mathrm{Cl}, \mathrm{OR}-0.5)$ which is contradictory to the present study findings. ${ }^{7}$

\section{Conclusion:}

Unmet need is still prevalent in the rural areas of Udupi district. Health professionals especially field staff should be trained to provide an informed choice to couples and also sufficient knowledge should be imparted regarding reproduction and contraception. 